\title{
the high wire and the long drop
}

\author{
Christopher Kelen
}

\begin{abstract}
C'est l'histoire d'une Chinoise à Macao, minuscule territoire anciennement portugais. À la merci d'un mari et d'un fils cruels, elle souffre terriblement et assiste à plusieurs reprises au suicide de voisins. Elle décide finalement de faire elle-même le grand saut, mais quand son mari sort par la fenêtre pour la ramener à l'intérieur, il semble que la corde à linge qu'il avait installée plusieurs années auparavant n'est pas aussi solide qu'il le pensait. Il résulte de cette suite d'erreurs de calcul une libération.
\end{abstract}

Hac Sa Wan. The hottest day of the year.

'Did you hear that thud?'

'No. Nothing.'

'It was unmistakable.'

'Sorry?'

'Sickening. You don't know what that was?'

'Look, I'm just trying to read my paper, dearest. A man can't get a moment's peace. All this infernal chatter. You just go on and on all the time. Can't you find someone else to nag at? Shouldn't you be cleaning something? The ghosts in hell have a quieter life than I have. And close that damn window. Don't you know how cold it is?'

Ah Mei is looking out of the window at the lifeless form on the ground below. She can't make out who it could be. It's a woman. The ghosts in hell? Here's another. Ah Mei, the wife in this piece, dwells bitterly on these words. She tries to guess from which floor this one fell. The ghosts in hell. It's unlucky but she can't help thinking of what ghosts in hell needn't put up with. Married life stretches back into her memory, back to girlhood. Back to where recollection fades and merges with whatever comes before it. When was she not a piece of furniture in this man's house? In her father's house before that? At least there though there'd been brothers and sisters to play with, there'd been school for a while, there'd been something other than drudgery and abuse.

This monster! Ah Mei glances across the room at his more than full form. She's careful not to catch his eye, that would be an accusation. And an accusation would lead to... The newspaper and the television, that's it. It's so long since he's worked, if he was given a job on a platter now, he wouldn't know what to do. He wouldn't have a clue. His sexual appetite may have diminished, his fondness for drink and for the violence it seems often as not to engender - these things have never lessened. Beating her up is how he keeps fit, he's actually said as much. Monster is no exaggeration. There's no animal she'd care to slander by making the association. Animals may be vicious in their nature, but they're innocents as well. 
Ah Mei feels old, she already feels something like how she imagines a ghost must feel. It's as if she is approaching the end at last, the end of a bitter life. It's not so much a premonition as a prognosis, a prognosis becoming a decision. She is alone. But not alone. Whenever they jump, and it's now happened four times in the last twelve months, either they fall past her window, or at least she hears the thud. Sometimes both. Once there was a scream, high pitched at first and then the pitch falling, for longer than she would have thought. In all but one case, she knows the women. She has played Mah Jong with them, or waited after school with them to collect kids. But that is all, was all, long ago. Now, they are gone, they're free. Where's she? Ah Mei admits to herself that, after each suicide, she had felt a thrill of empathy, she'd felt jealous. Her resentment had intensified.

'Where's my lunch?'

'I thought you were going out.'

'No. I never go out on Wednesdays.'

'You did last Wednesday and you said you would today.'

'No, I didn't. You're a lying bitch.'

But Ah Mei isn't lying. This is what she's put up with. It's worse than Alzheimer's because this is all meant, and vicious, every word of it. It's what he lives for now, this game of his, in which she is always wrong unless or until she takes a beating for remembering the truth. He does nothing but scheme against her now. When he'd had a job and gone out drinking and gambling, at least there'd been some respite then. One of the most attractive things about suicide would be the insurance money she'd be depriving him of.

'I'll get your lunch.'

'Hurry up, silly bitch or I'll...' but he drifts back to the paper not even bothering to finish his threat. He's so well understood.

Ah Mei thinks of the ways. There's the indoor BBQ option. It doesn't always work but they say that there's no pain. Slashed wrists and sleeping pills she's read are for attention seekers, people who aren't really serious. Though a hot bath helps apparently. Hell to clean though. Rat poison strikes her as an ugly way out. She's seen how the rats handle it. Pills? Or good old drinking yourself to death? Too expensive. Taking him with her? No, she's not that kind of person. No matter how evil for how long, no matter how much he deserves a fate grislier than she can imagine, she cannot take another life. But haven't these women of her acquaintance been showing her the way? The not-exactly-a-miracle of unpowered flight ... brief but heroic... What goes up? How natural could it be to live on the tenth floor anyway? There's hardly a cockroach up here. Well, there are less anyway. Unpowered flight. Freefall. The ride of a lifetime. It could be the one heroic thing in an otherwise astoundingly prosaic life... no, not even that is astounding... the dullness of her life is like the dullness of so many others... meaningless is the word that slips through her mind again and again. No meaning to live for.

But if she gives up the ghost? Then what? The Christians and the Daoists and the Buddhists and so many others, they can't all be right. No, but they could all be wrong. Annihilation, isn't that the goal of the good Buddhist? Well maybe 
it's only seconds away. But if there is a hell, my God, she thinks, I'll be poorer there than I have been in this life. None of those gangster children will send me any rice, and this monster, he wouldn't buy hell money for anyone apart his own revered father, that is, the man who taught him every blow he knows. Like father like son, and so Ah Mei reflects on the three generations.

'Lunch! Bitch! What's wrong with you?'

But something has changed, something has snapped inside. Ah Mei is actually climbing out of the window.

'I said lunch! It's freezing in here. Close that window dearest, or I'll throw you through it.'

'No need.'

'What?' But he doesn't even look around. Not yet.

She's still on the window-sill, dangling her legs, but she's edging herself onto the metal washing line. There are two of these actually. There's the original one from when the building was first erected, almost completely rusted out, and a newer one, itself ancient but not quite as rusty. That was a concession from him when they'd had three kids to wash clothes for. Cheaper than taking the washing out. She's sitting on the rusted line now. It's creaking a little but so far it's taking her weight.

There's that patch of silence in the script now where something funny has happened with time, so that none of the old rules apply, nor have they yet been superseded. Then the siren, desultory. Half a minute at the most. Just to acknowledge there's been an event. Like a bell tolling. Would it? The ambulance arrives. A waste. Why do they always send an ambulance for these corpses? Just a convention. She's swinging her legs now, and congratulating herself for being so thrifty, so thoughtful about things. Surely, they wouldn't send a second ambulance for her? This train of thought is only half bitter, only half ironic. Ah Mei has always been a thrifty soul. She's bouncing a little. There's a little creak.

'What the...?

And almost at the moment her husband has seen where she is, the ambulance men, looking up, naturally, have spotted her. They wave at her. She waves back. She's always loved meeting strangers.

'You get back in here, you stupid bitch.'

They signal they're coming up. One of them shouting out 'Don't... just don't. We're coming...'

'I told you to get back in here bitch.'

She doesn't even turn her head. 'No.'

'What was that?'

'No.'

'No what?'

'No I don't think so.'

'You get back in here and cook my lunch you filthy slut or I'll...'

'You'll what?'

'I'll shake you off that clothes line.'

'Go on then. Give me a Christian burial. Go to gaol. Everyone's watching.' 
'You're not a Christian. You never...'

'So?'

'I'll... I'll come out there and drag you back in and I'll give you a hiding you'll never forget...'

'Come on then.' Where is this bravery coming from? Ah Mei is discovering that simply by standing at the end of the world she is able to become a new person. Who would have thought it?

'Right.' And he's doing it. He's coming out. And Ah Mei is wondering whether the ambulance men will get to the door and then through the door before her husband succeeds in rescuing her and then carrying out the next part of his plan. But then she remembers that the lift was out this morning, so they'll be a while yet.

It's hard for this slug to get out the window. He's struggling. Ah Mei's moved to the furthest edge of her line. It's remarkably strong! Or she's remarkably light? Maybe she's a ghost already. In any case he can't reach her from the window. So he's climbing through. He's coming.

Another siren. It's emergency services. Might as well have a send off. He's on the window sill now. He's so angry. But it's so funny to see him there. How will he ever swing his legs around to get himself whole through the window? It's inconceivable.

She's looking down. She's decided to spend her last few minutes ignoring her lifelong tormentor. Condemned men get cigarettes and pizzas. It's not as if she's asking much. They're waving up at her, these new boys. And she's waving back. They're so young. And they really seem concerned. It's touching. When was the last time someone had shown concern for her? What are they doing? They've dragged some enormous plastic thing out of their truck. What is it? She hears the puffing and the panting behind her, but she's not going to turn around. Not now. She's decided. She's never giving that bastard the satisfaction again.

It's a jumping castle. They've got me a jumping castle from a kids' fair. Now that is sweet. She looks around for the contrast and she's shocked to see he's swung his legs around. He's actually sitting on the window sill, legs out. He's catching his breath after this super human effort. Without making eye contact she can see that he's scared. She's still beyond his reach. She waves down to the boys again. They shout back something she can't make out. One of them's going for a megaphone in the truck. She swings her legs, she tests her position. She bounces a little. She feels like a girl again. When she glances back, he's more scared than ever. Scared and angry, but which more? Some kind of table has turned. This is all worthwhile. She's glad she didn't go for the charcoal or the rat poison. She's out in the fresh air. There's something wholesome about this. He's looking determined now. He's going to get her. He's in that mood he gets in, just before the violence, when he stops talking altogether. He's about to climb off the ledge and onto the clothes line. She means to say nothing, to ignore him. They've started up a pump down below. It's so loud that even with the megaphone she can't hear a thing they're shouting. 
The wonderful thing is that with all these unexpected events, she's completely forgotten to feel afraid for herself. She means to say nothing but she can't help herself. She says, 'It'll never take your weight.'

'It will.'

'It won't'

'It will. You are such a contrary bitch. Even now, you have to contradict me. It's the new one. I put it up myself. I put in the biggest bolts we could afford. It'd take two of me.'

'Maybe then. Not now. You're too heavy.'

'Just watch.'

She does. There isn't really a moment when he has hold properly. Why didn't time stand still this time? The whole operation is so noiseless, such a nonevent. Just the pump working, a dull thud barely heard above it.

Down below they're thinking again about that proposal for the faster pump. It should really be no problem now. 'Shit! And there's still another one. They must be having a convention today. Can't that thing go any faster? Better get another ambulance. They'll only fit two in there.'

It's only another minute and things are fully inflated down below. The pump's turned off and now it's a little surreal, she can hear everything. Of course there's a crowd gathered too. She's a celebrity. Some callous youth is yelling, 'Throw us your wallet, love. You won't need it.' But Ah Mei's in casual attire. She wasn't dressed to go out and even if she had been, well, that cheapskate husband wouldn't have let her have fifty patacas in her purse. So quite frankly her wallet would be a disappointment to any potential grave robber. What's going through Ah Mei's head is, 'greedy little bastard'. This sentiment and the train of thought preceding it, she recognises, are all signs of the will and the determination to live. And why not, she has her whole life ahead of her. Instead of being saved by a cave man for his mindless abuse, they've prepared a castle to catch her. Of course she wants to live. Her life begins this moment. That's why she jumps. She aims and jumps. She'll feel sore but it'll be worth it.

And now comes the pounding on the door. Then the crowbars. Two panting men storm into an empty room. They look down to see a woman still bouncing. She looks remarkably... sprightly's the word. No harm done. They don't even notice the male body, which is odd, given how much pavement it takes up and the conspicuous chalk marks already around it.

For Ah Mei, celebrity status. A certain amount of the naughty girl treatment, but after all she's been through, they're gentle with her. There's the obligatory ambulance ride down to the hospital for the check up. 'How was that?' quips the ambulance man, as he helps her aboard.

'It was great. Great. I've never felt so alive in my life.'

'That's what we like to hear', he says, but he's thinking 'and that's the first time I've heard it.'

It's on her way home from the hospital, social worker in tow, the wheels begin to turn. One thing she realises straight off is the simple fact that this wasn't a suicide. There's no way it was. There are witnesses. The situation is quite clear 
cut. The doctor, the social worker, the policeman: none of them had any trouble believing her story, which was simply the truth. She told him it wouldn't take his weight. She told him. The truth will set you free. Maybe the Christians are onto something? Ah Mei knows she'll be collecting a tidy sum. A new flat? Maybe Coloane? Fresh air out there. Sea breezes. Maybe she'll take up sky diving. Hang gliding. Parachuting. Never too young to learn. 